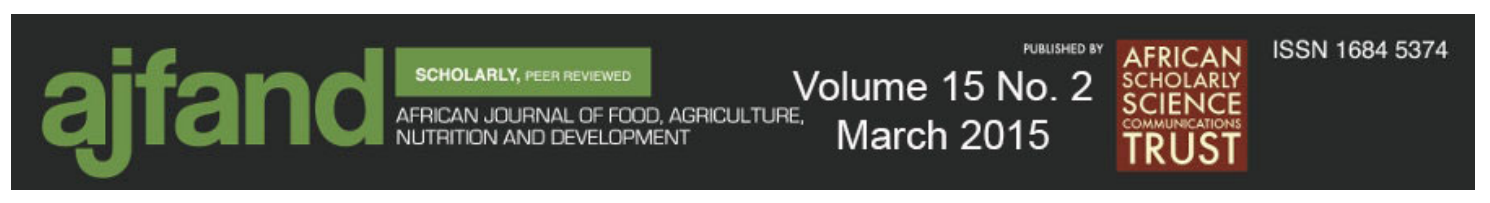

\title{
OPTIMUM RESOURCE ALLOCATION AMONG SELECTED \\ SMALLHOLDER ROOT AND TUBER CROPS FARMERS IN ABIA STATE, NIGERIA
}

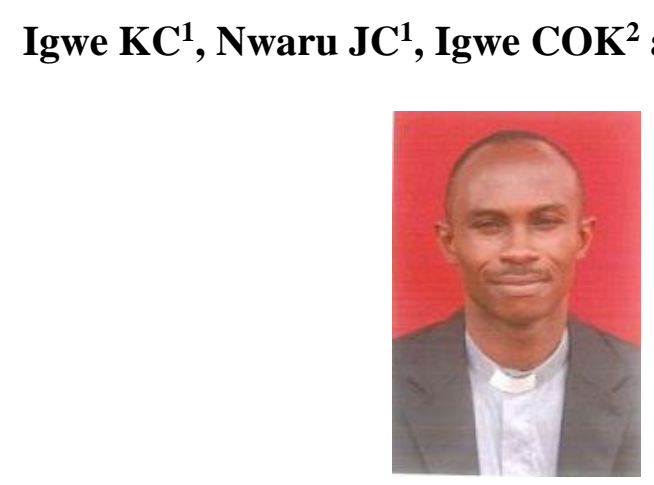

Kelechi Igwe

*Corresponding author email: kayceigwe@gmail.com

${ }^{1}$ Department of Agricultural Economics, Michael Okpara University of Agriculture, Umudike, P. O. Box 2, MOUAU Post Office, Umudike, Abia State, Nigeria

${ }^{2}$ Extension Services Programme, National Root Crops Research Institute, Umudike, P.M. B. 7006, Umuahia, Abia State, Nigeria 


\section{ABSTRACT}

This study examined optimum cropping patterns for selected root and tuber crop based production and resource allocation of smallholder farmers in Abia State, Nigeria, using the linear programming approach. The objective function was to maximize gross revenue from the production of selected root and tuber crop based production activities subject to land, labour and minimum subsistence family staple food consumption. Cost route approach was used to collect data from a random sample of 60 smallholder farmers in the state using the multistage stratified technique for location. The activities incorporated in the LP model include crop production activities, labour activities and product selling activities. Crop production activities comprise sole crops and crop mixtures. Existing selected crop activities were compared with their optimum counterparts. Resource allocation was compared between farm land owners and tenants with the aim of investigating their relative competitiveness in major root crop based production combination. Results showed that the sampled farmers were not optimal in their resource allocation. There was gross misallocation of labour for both land owners and tenant farmer. For the selected root and tuber crops, yam, cocoyam and cassava crop activities were found in their soles in the existing plan whereas crop mixtures were dominance in the optimal plan except cocoyam for the tenants' category. However, optimal farm plans favoured fewer crops than in the existing plan. Cassava/melon, yam/maize and cocoyam/melon were the crop activities prescribed for an average land owner to maximize gross margin of N231,119.40K as against N190,265.00K in the existing plan (an increase of 21.48\%) while for the farm tenants N190,671.30K was prescribed as optimal gross margin as against N184,600.00K (an increase of 3.29\%). Yam/melon and Cassava/cocoyam/maize had the least tendency to depress farm income if forced into the plan for the land owners and farm tenants respectively. Farmers' purchasing power would be enhanced given optimal crop production activity combination and land resource allocation.

Key words: Optimum, activities, crops, smallholder farmers 


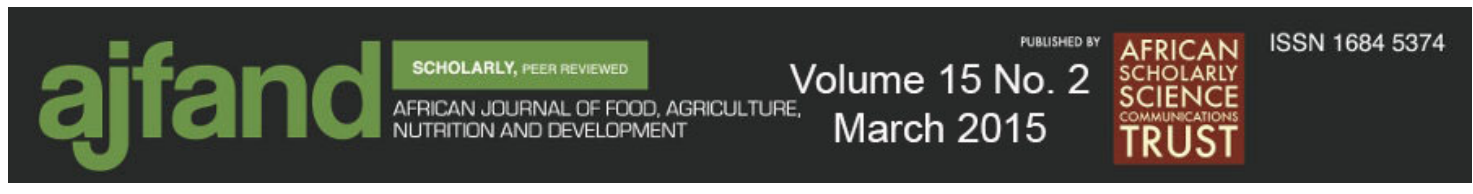

\section{INTRODUCTION}

Smallholder farmers predominate the agricultural sector in Nigeria and are estimated to contribute $90 \%$ of the total food output [1]. These farmers are faced with the challenge of rationing and optimizing scarce resources among intended activities as well as optimising the result of the rationing [2].

In linear programming models, the objective of a typical farm or farmer be it maximization of net profit or gross margin or cost minimization of production is achieved through optimal plan derived from the simplex algorithm at the final plan. A typical small scale farmer has limited levels of such resources as capital, labour (skilled or unskilled), machine, farm buildings and land which limit the scale of operation; and is encumbered with the problem of myriad of choices for allocating farm resources among competing enterprises to optimize production objectives. Identifying the best farm plan therefore posses a difficult task in farm planning decisions. Information on the optimal allocation of resources as to what crop activities to undertake, how much land to allocate among competing crop activities and what method and combinations of inputs to use on each crop activity so that net farm incomes are maximised is crucial to the farmer [3]. For this study, however, focus was on gross margins aimed at determining the optimum resource allocation for combination of enterprises for selected root and tuber crops based production activities.

\section{METHODS}

The study Area: This study was carried out in Abia State of Nigeria which lies within latitudes $4^{\circ} 45^{1} \mathrm{~N}$ and $6^{\circ} 17^{1} \mathrm{~N}$ of the equator and longitudes $7^{\circ} 00 \mathrm{E}$ and $8^{\circ} 00 \mathrm{E}$ of the Greenwich Meridian. It has a tropical climate that is humid all year round, with the rainy season that starts from March to October and dry season that occurs from November to February [4]. The state's agriculture is rain fed and the rainfall pattern is bio-model with peaks in July and September [5]. Current Census statistics put the State at a total population of 2,833,000 [6] out of which 95\% are said to be Christians [4]. Abia State has about thirty eight (38) blocks, two hundred and twenty eight (228) circles and one thousand, eight hundred and twenty four contact farmers, with each farm family consisting of about 5-10 members who are mainly small-scaled farmers [7].

The Data: The multistage stratified random sampling technique was used in choosing the respondents. Firstly, each of the state's agricultural zones was stratified based on extension blocks from which a block was selected at random. Secondly, each chosen block was further stratified based on extension circles bearing in mind where there is concentration of major root crop particularly cassava and yam based production activities from which a circle was selected at random. Thus, three circles were selected for the study because of the depth of data collection. Thirdly, each circle was then stratified based on villages from which two villages were randomly selected for each circle. In the fourth stage a list of farmers in each village was compiled with the assistance of village heads and agricultural extension agents from which 10 farmers in each village were randomly selected for the study. This gave a sample size of 60 farmers in the state. 


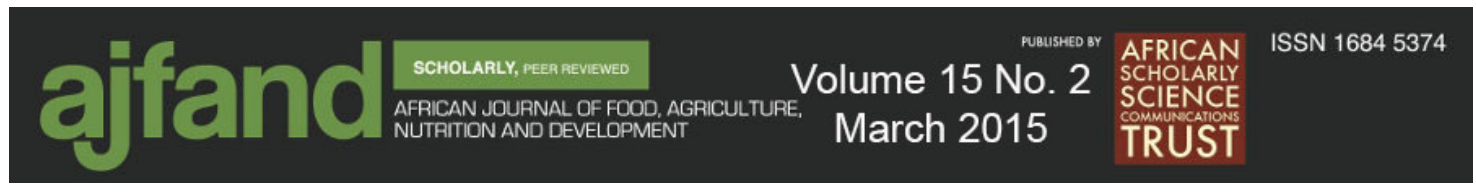

Data were collected using two sets of pretested structured questionnaire complemented with interview schedule because of the rigorous nature of data collection. Farmers were generally not literate to handle the filling of the questionnaire on their own without assistance and were also not willing to spare so much time with the researcher, and so, an interview with the farmer became necessary. The first set was used to collect data once, that is, on a single visit basically on the socioeconomic characteristics of the sampled farm households and the second set was used to obtain data following the farm households from the time of planting to time of harvesting of their farm produce but on a fortnightly visit. It is basically data from this second questionnaire that the study was based on. Two trained enumerators with socio-economic research background assisted the extension agents in the villages during the data collection exercise.

The Model: A linear programming model essentially similar to that used among farmers in India and Nigeria respectively guided the modelling $[8,9]$. The major variation was that in this study a single land restriction was modelled and there was no formal capital borrowing by the farmers. The model was specified as follows:

$\operatorname{Maximize} \mathrm{Z}=\sum_{\mathrm{j}=1}^{n} \mathrm{G}_{\mathrm{j}} \mathrm{X}_{\mathrm{i}}-\sum_{\mathrm{t}=1}^{4} \mathrm{~W}_{\mathrm{j}} \mathrm{L}_{\mathrm{t}}-\sum_{\mathrm{t}=1}^{3} \mathrm{M}_{\mathrm{t}}-\sum_{\mathrm{k}=1}^{\mathrm{n}} \mathrm{P}_{\mathrm{k}} \mathrm{Y}_{\mathrm{k}}$

Subject to:
$\sum_{\mathrm{j}=1}^{n} \mathrm{I}_{\mathrm{js}} \mathrm{X}_{\mathrm{i}} \leq \mathrm{L}_{\mathrm{s}}$ (land) $(\mathrm{s}=1)$

$\sum_{j=1}^{n} \operatorname{ajtX}_{j}-L_{t} \leq$ Ht (Human labour, $\left.t=1,2,3,4\right)$

$\sum_{j=1}^{n} \operatorname{cjtX}_{j}-\mathrm{C} \leq \mathrm{C}_{\mathrm{t}}$ (Capital)

$\sum_{n=1}^{n} F_{k} X_{j} \geq F_{(\min )}($ Minimum subsistence farm family staple requirement $(k=1,2 \ldots . m)$

$$
\mathrm{X}_{j}, \mathrm{~L}_{t}, \mathrm{M}_{t}, \mathrm{P}_{K} \geq 0
$$

Where $\mathrm{Z}$ is total gross margin in naira, $\mathrm{Gj}$ is gross margin of the jth crop activity in Naira, $\mathrm{Xj}$ is hectares of the jth crop activity, Ls is the total available land in hectares for the crops with $\mathrm{s}$ restrictions, $\mathrm{W}_{\mathrm{j}}$ is wage rate per unit of human labour in naira per mandays in the $t^{\text {th }}$ period, $\mathrm{Lt}_{\mathrm{t}}$ is number of human labour hired or family in th period, $\mathrm{Ht}$ is total available labour in man-days in the $t^{\text {th }}$ period. Mt is working capital in naira in the the $t^{\text {th }}$ period, $\mathrm{P}_{\mathrm{k}}$ is marketing expense per unit of the $\mathrm{k}_{\mathrm{th}}$ crop sold, $\mathrm{Y}_{\mathrm{k}}$ is quantity of the $\mathrm{k}_{\text {th }}$ crop sold, $F_{k}$ is yield of the kth crop per hectare of the jth crop activity, $\mathrm{C}$ is capital borrowed in naira, $\mathrm{C}_{t}$ is total working capital owned/available in Naira in $t_{\text {th }}$ period, Fmin is the minimum quantity of staple (cassava/yam/maize) required by the farm family per annum 
in tons, Ijs is input coefficient of land which is a hectare with s restriction, aj is input coefficient of human labour in man-days per hectare of the jth crop activity, and cjth is the amount of capital in Naira used in producing one hectare of the jth crop activity in tth period and $\Sigma$ is summation of $j$ th crop activities ( $j=1$ to $n$ ).

The objective function (equation 1), is to maximize total gross margin of producing the crops less costs of labour and marketing. With regard to the constraints, equations 2 and 3 require that total quantities of land, and human labour are not to exceed availability. Equation 5 specifies the minimum subsistence farm-family staple requirements while equation 6 requires that the decision variables be non-negative. The model was used to derive optimum farm plans for farm owners and tenants' situations for selected major root crop enterprises.

Activities in the model: The activities in the model are broadly grouped into crop production activities, labour, and product selling activities. The crop production activities comprise sole crops and crop mixtures. The unit of each production activity is one hectare. The price coefficient of each production activity is gross margin per hectare (total revenue less total variable cost of production). For the human labour activity, the price coefficient is the ruling wage rate (naira per man day). Capital was captured as working capital required for day to day farm production expenses besides human labour, that is, the planting materials and all the agrochemicals etc. but was not defined as an activity of its own.

Product selling activities facilitate the sale of the final output realized from the various cropping activities. Each production activity may have more than one selling activity depending on whether such activity is sole crop or mixed crop.

Restrictions in the model: The restrictions incorporated in the model are as follows: Land: Agricultural land in Abia State can be categorized into two mainly irrigated/fadama land and the rain fed farm land. For the purpose of modelling, classification was not based on irrigated or non-irrigated lands with recourse to parent material of the agricultural land. Classification for the purpose of modelling for this study was non-irrigated land and thus a single land restriction was modelled. However, there are basically two land ownership classifications for which comparison was made.

Human Labour: Human labour restrictions were imposed on the model by taking into account seasonal farm operations requirements of labour for different crops. Thus, four human labour restriction periods were specified for (1) land preparation and planting (2) first weeding (3) second weeding. (4) Harvesting. Wage rate is the remuneration per manday of labour; however, one man-day corresponds to 8 working hours for an adult male.

The periods for different management practices that informed the restrictions were:

a) February - April $=$ period for land preparation and planting

b) May - June $=$ period for first weeding

c) July - September $=$ period for second weeding

d) October- December $=$ period for harvesting of available crops 


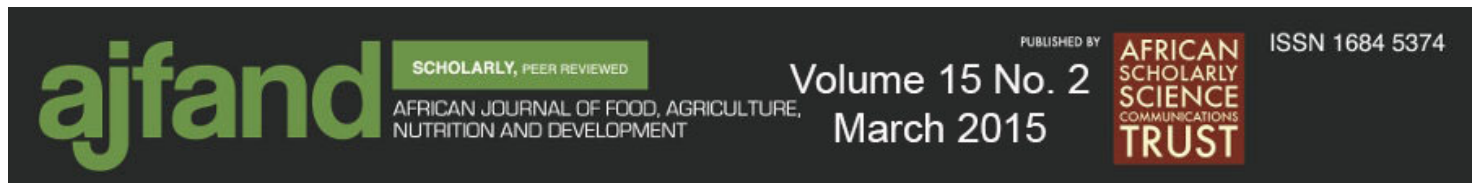

Minimum staple requirements: Minimum annual staple requirement of each household in terms of cassava, yam or maize was obtained from each farm household. It was estimated that an average farm household would require a minimum staple per annum irrespective of land ownership status in other to meet the family food needs.

\section{RESULTS}

\section{Optimum combination of crop activities}

The optimum crop activities combinations for land owners and tenants are presented in Table 1.

Whereas four crop production activities were entered into the optimal plan for the tenants' category, only three activities were prescribed for the land owners' category in the optimal plan. Out of the ten possible activities only three-cassava/melon, yam/maize and cassava/cocoyam/melon entered the optimal solution for land owners.

\section{Existing and optimum land and labour resource allocation:}

The results of the existing and optimum patterns of resources allocation as well as the gross margin for both land owners and tenants are presented in Table 2.

\section{Shadow prices of excluded activities:}

The shadow prices of land owners and farm tenants are contained in Table 3.

Shadow prices in this context are by-products of LP solution. Their values as contained in Table 3 show in monetary terms the amount by which the total gross margin will be reduced if any of the excluded activities were forced into the programme.

\section{DISCUSSION}

\section{Optimum combination of Crop activities:}

The prescribed total cropped area for an average farmer under this category is 0.593 hectares. However, for the tenants farmers, out of nine crop production activities observed in the existing plan, only four crop activities namely cocoyam, cassava/maize, yam/maize and cassava/cocoyam/melon entered the optimal solution. Among the crop mixtures cassava based production activities dominated the optimal plan for both land owners and tenants farmers. It was only in the tenants that a sole root crop entered the plan. Yam/maize was found in both cases.

Cassava based crop mixtures relatively dominated the activities across the two categories followed by yam based enterprises. However, tuber crop based mixture occupied more land than the root crop based for land owners. Sole crop production activity was favoured in the plan for the tenant category, implying that possible mechanization given available land is more likely to be achieved among tenants' farmers than the land owners' category particularly for cocoyam production activity.

\section{Existing and optimum land and labour resource allocation and Gross Margin:}

Achieving commercialization of agriculture can only be favoured as agriculture is managed by business minded farmers who are not subsistence oriented at all in carrying 


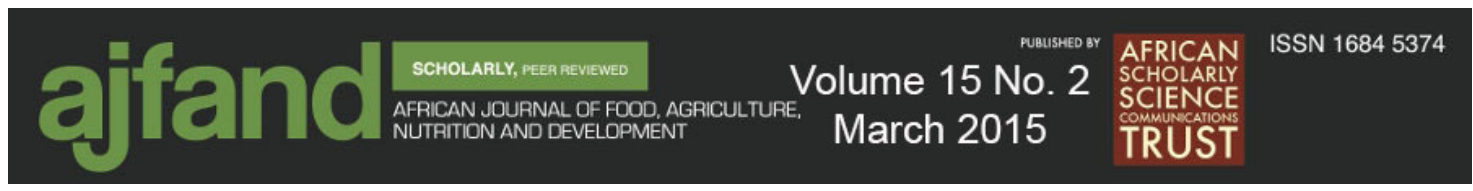

out their agricultural production. Given the small landholdings of the sampled farmers as shown in Table 2, only semi-commercial agriculture is possible in the area as profit maximization is not the only objective of the farmers. It goes to infer that agricultural intervention by government and donor agencies should target this group of farmers to move agricultural transformation to the desired frontier.

Land resources were more in the existing plan than the optimum plans for both categories of farmers. However more of the land was utilized in the optimum for tenants relative to the farm owners.

Employment of labour decreased by $37.23 \%$ and $46.59 \%$ over the existing pattern for farm owners and tenants, respectively. Labour resource allocation is lower under tenants than land owners and vice versa for land resources.

The gross margin increased by $21.48 \%$ for farm owners and $3.29 \%$ under tenants farms. The gross margin exceeded their actual values. This is in consonance with results obtained among smallholder farmers in India [3] and by other researchers in Nigeria [9, $10,11]$.

\section{Shadow prices of excluded activities:}

The results shown in Table 3 means that if sole yam is forced into the plan for the farm tenants, the value of the total gross margin would be reduced by N26, $551.80 \mathrm{~K}$ while the inclusion of a hectare of cassava/maize enterprise into land owners' optimal plan would reduce the value of the gross farm income by N35, 950.32K.

By implication, therefore, the higher the shadow price of an excluded activity, the lower is its chance of being included in the final plan. It has generally been observed that shadow prices of sole crops are higher than those of crop mixtures. In a maximization problem, shadow prices are income penalties. It has been reported that one of the fundamental problems facing extension agents has been to persuade peasant farmers to grow crops as sole stands [12]. However, available research evidence seem to support the peasant farmers' persistence in the use of intercropping and challenged the assertion that sole cropping is superior to intercropping under the peasant agricultural set up by indicating that intercropping generates greater cash returns per hectare [13].

The accumulation of income or economic considerations is not the only factor that farmers take into account before including certain activities in the crop mixtures. The decision to produce also includes farm family food. The argument by some studies to discourage intercropping is often based on findings of researches that involved sole cropping conducted on research stations that employed improved technology. It is, therefore, out of order to apply such to smallholder farmers encumbered with conflicting challenges of producing food to feed household members and surplus for the market. 


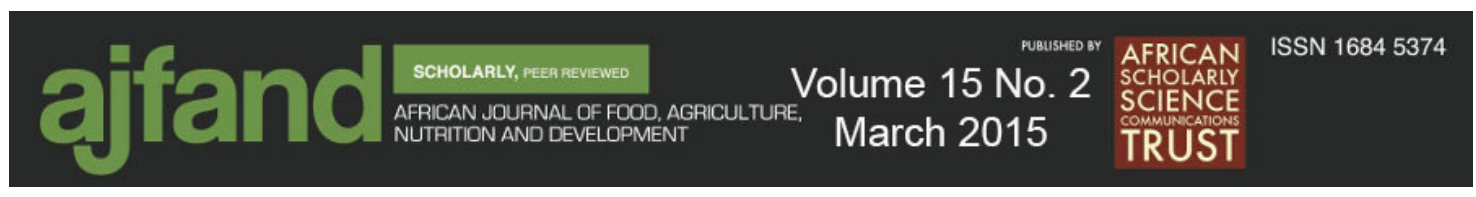

\section{CONCLUSION}

Staple foods of many farm households in the South-East Nigeria particularly for Abia State have largely revolved around the major root and tuber crops especially cassava and yam. The optimization of crop activity combination and resource allocation among farmers who engage in related crop production is cardinal to improving not only the rural life of the people but also the health status of the farming community in particular and the State in general. The linear programming approach was used to develop a prototype package for these farmers who are semi-commercially oriented and which if they should adopt would improve their production capabilities and reasonably improve their gross income. 


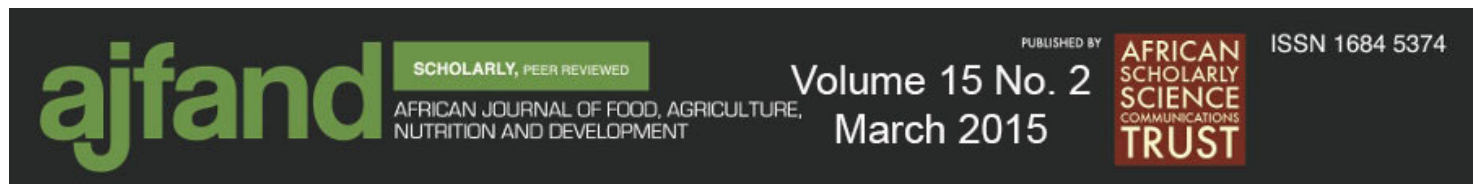

Table 1: Optimum combination of crop production activities (ha)

\begin{tabular}{lllc}
\hline S/N & Crop Activities & $\begin{array}{l}\text { Land } \\
\text { Owners }\end{array}$ & Tenants \\
\hline 1. & Cocoyam & - & 0.117 \\
2. & Cassava/maize & - & 0.163 \\
3. $\quad$ Cassava/melon & 0.147 & - \\
& & & \\
4. $\quad$ Yam/maize & 0.225 & 0.187 \\
& & & \\
5. Cassava/cocoyam/melon & 0.239 & 0.128
\end{tabular}

Source: Farm Survey, 2010 


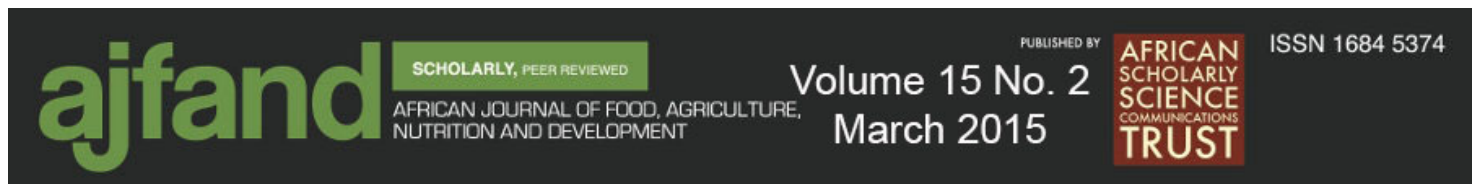

Table 2: Existing and optimum patterns of land and labour resource allocation

\begin{tabular}{|c|c|c|c|}
\hline Resource & Existing Plan & $\begin{array}{l}\text { Optimum } \\
\text { Plan }\end{array}$ & $\begin{array}{l}\text { Increase/Decrease over } \\
\text { existing Plan (\%) }\end{array}$ \\
\hline \multicolumn{4}{|l|}{ 1. Land (hectares) } \\
\hline a. Farm/land Owners & 1.90 & 0.61 & 67.90 (1.29ha) \\
\hline b. Farm/land Tenants & 1.50 & 0.94 & 37.33 (0.56ha) \\
\hline \multicolumn{4}{|c|}{ 2. Human labour (man-days) } \\
\hline a. Farm owners & 148.50 & 93.22 & 37.23 (55.28mandays) \\
\hline b. Farm Tenants & 133.90 & 71.52 & 46.59 (62.38mandays) \\
\hline \multicolumn{4}{|c|}{ 3. Total Gross Margin (Naira) } \\
\hline a. Farm owners & 190,265 & $231,119.40$ & $-21.48(\mathrm{~N} 40,854.40)$ \\
\hline a. Farm tenant & 184,600 & $190,671.30$ & $-3.29(\mathrm{~N} 6,071.30)$ \\
\hline
\end{tabular}

Source: Farm Survey, 2010

NOTE: The actual difference between the existing and the optimum are specified in parenthesis 


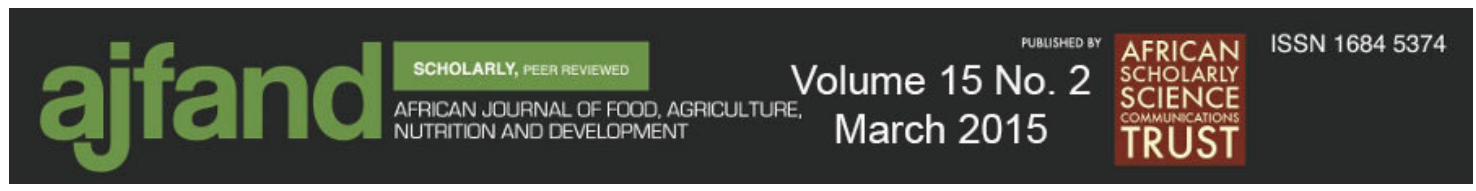

Table 3: Shadow prices of excluded activities in Naira

\begin{tabular}{|c|c|c|c|}
\hline $\mathbf{S} / \mathbf{N}$ & Activities & $\begin{array}{l}\text { Land } \\
\text { owners }\end{array}$ & Tenants \\
\hline 1. & Yam & 11226.30 & 26551.80 \\
\hline 2. & Cassava & 13885.58 & 991.23 \\
\hline 4. & Cassava/Yam & 22969.44 & \\
\hline 5. & Cassava/Maize & 35950.32 & \\
\hline 6. & Cassava/Melon & & 8877.02 \\
\hline 7. & Yam/Melon & 7368.52 & 20456.42 \\
\hline 9. & Cassava/Yam/Maize & 28537.31 & \\
\hline 10. & Cassava/Cocoyam/Maize & 5543.58 & 601.90 \\
\hline
\end{tabular}

Source: Farm Survey, 2010 


\section{REFERENCES}

1. Olayemi JK Food Crop Production by Small Farmers in Nigeria. In: Nigeria Small Farmers: Problems and Prospects in Integrated Rural Development, Olayide, S. O., Eweka, J. A., Bello-Osagie, V. E. (eds) Centre for Agriculture and Rural Development, University of Ibadan, Nigeria. 1980.

2. Olayemi JK and CE Onyenweaku Quantitative Methods for Business Decisions. Bosude Printers Limited, Ibadan, Nigeria. 346p. 1999.

3. Singh K Optimum Land Use Pattern and Resource Allocation in a Growing Economy. Indian J. Agric. Econ, 1778; 33(1): 44-58.

4. Igwe KC Optimum Combination of Arable Crops and Selected Livestock Enterprises in Abia State, Nigeria: A Linear Programming Approach, $\mathrm{PhD}$ Dissertation Submitted to Post graduate School, Michael Okpara University of Agriculture, Umudike, 112p. 2012.

5. Tanko L and CA Opara Profitability and Resource Productivity of Sole and Intercropping in Ikwuano Local Government area of Abia State, Nigeria. Proceedings of the $40^{\text {th }}$ Annual Conference of the Agricultural Society of Nigeria held at Umudike, October $16^{\text {th }}-20^{\text {th }}, 167-170.2006$.

6. National Population Commission, NPC National Census. National Population Commission’s Report, October, Abuja, Nigeria. 2006.

7. Oriaku SEO Effectiveness of Contact Farmers in the Diffusion of Agricultural Innovations in Umuahia Agricultural Zone of Abia State. MSc Thesis, Department of Agricultural Economics and Extension, Abia State University Uturu. 2008.

8. Alam MS, Elias SM and MM Rahman Optimum Land Use Pattern and Resource Allocation in a Growing Economy: A Closed Model Approach, Bangladesh J. Agric. Economics XVIII, 1995; (2): 15-37.

9. Onyenweaku CE and L Tanko Optimum Combination of Enterprises and Resource Allocation by Arable Crop Farmers in Kebbi State, Nigeria. Journal of Sustainable Tropical Agricultural Research 2005; (14): 81-88.

10. Igwe KC, Onyenweaku CE and JC Nwaru Optimum Combination of Arable Crops and Selected Livestock Enterprises among Farmers in Abia State, Nigeria. International Journal of Applied Research and Technology 20121 (6): 72-82.

11. Igwe KC and CE Onyenweaku A Linear Programming Approach to Food Crops and Livestock Enterprises Planning in Aba Agricultural Zone of Abia State, Nigeria. American Journal of Experimental Agriculture (AJEA) 2013; 3(2): 412-431 www.sciencedomain.org (accessed: 14-09-2013). 
12. Nwosu AC (1981) Cropping Pattern and Resource Productivity: A Comparative Analysis of Profitability in Sole and Intercropping. Nigerian Journal of Agricultural Science 3(1): 24-27. 1981.

13. Tanko L and KM Baba Raising Income Level of Farmers in Niger State, Nigeria: A Linear Programming Approach. Research Findings Report, Funded by the University Board of Research (UBR), Federal University of Technology, Minna, August, 55p. 2010. 